e-ISSN: $2621-8119$

\title{
TEKNOLOGI MEMBRAN ULTRAFILTRASI UNTUK PENGELOLAAN AIR LIMBAH PENCUCIAN INDUSTRI TEKSTIL ECO-PRINT
}

\author{
ULTRAFILTRATION MEMBRANE FOR TREATING TEXTILE WASTEWATER OF ECO-PRINT \\ INDUSTRY
}

\section{Erna Yuliwati, Sri Martini, Ani Melani}

Universitas Muhammadiyah Palembang

*Korespondensi Penulis, email : deeyuliwati@gmail.com

Diterima : 27 November 2020

Direvisi : 29 April 2021

Diterbitkan : 30 Juni 2021

\begin{abstract}
A microporous hydrophobic membrane for textile wastewater has been extensively reviewed and discussed. Many investigations attempted the use of polyvinylidene fluoride (PVDF) membranes to separate the textile wastewater. Using hydrophobic membranes, textile wastewater is normally produced as permeate. Meanwhile, hydrophilic membranes can produce water which was free of grease and organic matter content as permeate. PVDF membrane was modified by chemical treatments in order to obtain a functionalized polymer suitable for preparation of membranes with improved the hydrophilicity and fouling resistance. The addition of organic or inorganic hydrophilic material in casting dope to prepare porous membranes by phase inversion method was an effective technique to improve the flux and amount of wastewater removal process. PVDF membranes were found to be an effective membrane material for treatment of textile wastewater with modifying structural on roughness $12.28 \mathrm{~nm}$, $18.65 \mathrm{~nm}$ and $20.58 \mathrm{~nm}$ with adding $3 \%, 5 \%$ and $10 \%$ of $\mathrm{TiO}_{2}$. These resulted on flux of $142.92 \mathrm{~L} / \mathrm{m}^{2} . \mathrm{hr}$ and decreased COD, BOD and TOC of $90.08 \%, 85.92 \%$ and $92.34 \%$, respectively.
\end{abstract}

Keywords: Eco-print wastewater, polymer membrane, ultrafiltration, $P V D F$

\begin{abstract}
ABSTRAK
Membran hidrofobik mikro untuk air limbah tekstil telah ditinjau dan didiskusikan secara ekstensif. Banyak penelitian mencoba menggunakan membran polivinilidena fluorida (PVDF) untuk memisahkan air limbah tekstil. Menggunakan membran hidrofobik, air limbah tekstil biasanya diproduksi sebagai permeat. Sedangkan membran hidrofilik dapat menghasilkan air yang bebas lemak dan kandungan bahan organik yang merembes. Membran PVDF telah dimodifikasi dengan perlakuan kimia untuk mendapatkan polimer yang berfungsi sesuai untuk persiapan membran dengan meningkatkan hidrofilisitas dan ketahanan terhadap pengotoran. Hasil penelitian ini menghasilkan permukaan luar PVDF membran berongga. Hasil dari analisis AFM mengungkapkan bahwa permukaan membran tidak mulus dan struktur seperti nodul dan agregat nodul terbentuk pada permukaan membran PVDF. Derajat kekasaran permukaan $(\mathrm{Ra})$ dihasilkan masing-masing sebagai $12,28 \mathrm{~nm}, 18.65 \mathrm{~nm}$ dan 20,58 nm untuk PVDF dengan $3 \% \mathrm{TiO}_{2}$, PVDF dengan $5 \% \mathrm{TiO}_{2}$ dan PVDF dengan $10 \% \mathrm{TiO}_{2}$. Hal ini dapat meningkatkan fluks mencapai $142,92 \mathrm{~L} /$ $\mathrm{m} 2 \mathrm{~h}$ dengan pengurangan persentase COD sebesar 90,08\%, BOD sebesar $85,92 \%$ dan TOC sebesar $92,34 \%$.

Kata Kunci : Limbah cair Eco-print, membran polimer, ultrafiltrasi, PVDF
\end{abstract}




\section{PENDAHULUAN}

Membran telah menjadi salah satu teknik pemisahan yang dapat diandalkan terutama pemisahan air. Mereka digunakan di berbagai industri dan pabrik seperti desalinasi, pemurnian air dan pabrik pengolahan air limbah. Salah satu aplikasi membran berpori yang terkenal dalam pengolahan air limbah adalah membuat emulsi dengan ukuran yang berbeda (Liese, W., \& Kohl 2015). Metode ini didasarkan pada kemampuan tekanan rendah untuk fase terdispersi meresap melalui membran ke dalam fase kontinu dan berlaku untuk emulsi minyak-dalam-air dan air-dalamminyak. Limbah cair dalam jumlah besar dalam bentuk emulsi dihasilkan dalam industri proses, seperti petrokimia, farmasi, air cucian, minyak bumi, metalurgi, dan transportasi. Meningkatnya popularitas polimer jenis polyvinylidena fluoride (PVDF) dalam proses pengolahan air limbah cucian terutama dikaitkan dengan ketahanan kimia dan stabilitas termal yang sangat baik.

PVDF adalah polimer semi-kristal yang mengandung fasa kristal dan fasa amorf dan / atau kenyal. PVDF stabil saat diserang oleh sebagian besar bahan kimia korosif dan senyawa organik termasuk asam, basa, oksidan kuat, dan halogen (N. 1967), (Han and Xiaona Niu 2012). Properti unggul ini menghasilkan bahan membran yang luar biasa terutama untuk aplikasi pengolahan air limbah industri yang melibatkan emulsi sabun dan zat warna (dye) (Kusworo, T.D., Pratama, B.A. 2020), pemisahan organik/air (Yuliwati and Ismail 2011), penyerapan dan pengupasan gas (Kusworo, T.D., Pratama, B.A. 2020), distilasi membran (S.C., Yu, S.C. \& Gao 2017), dan ultrafiltrasi (Yuliwati and Ismail 2011). Selain itu, kemampuan membran untuk menahan paparan suhu tinggi $366 \mathrm{~K}$ dalam waktu lama dan PVDF dapat diautoklaf untuk aplikasi yang disterilkan (biasanya pada $121^{\circ} \mathrm{C}$ ) (Yuliwati, E. et al. 2011).

PVDF sering dikelompokkan bersama dengan polypropylene (PP), Polytetrafluoroethylene (PTFE). Dari ketiga polimer tersebut, hanya PVDF yang dapat dibuat menjadi membran asimetris dengan metode inversi fasa. Sebagai polimer semi-kristal, PVDF umumnya menunjukkan perilaku pemisahan fase yang lebih rumit daripada polimer amorf (Yuliwati, E. et al. 2011), (Yuliwati and Ismail 2011). Pertumbuhan kristalinitas polimer memiliki efek merugikan pada sifat transfer membran karena keduanya menurunkan volume bebas daerah amorf yang tersedia untuk transpor spesies dan meningkatkan membran yang memiliki pori yang tersebar merata dan lubang pori yang berliku-liku (Ezekannagha, Ude, and Onukwuli 2017), (Yuliwati et al. 2011).

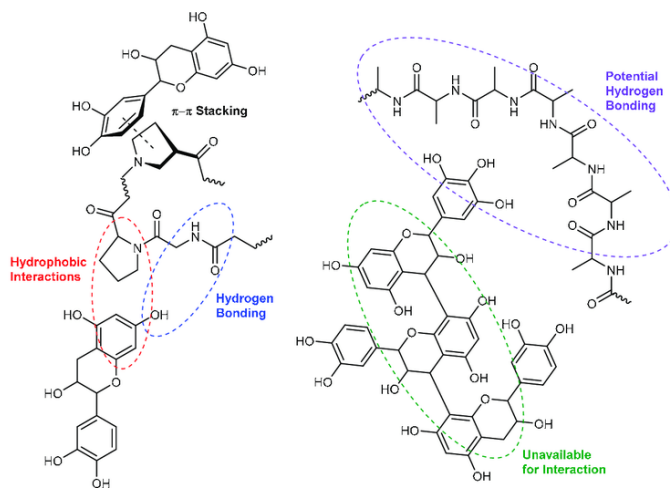

Gambar 1. Interaksi hidropobik dan ikatan hidrogen dalam pembuatan membran.

Gambar 1 mengilustrasikan bentuk struktural monomer hidropobik yang digunakan sebagai bahan utama polimer pembuat membran. Pada proses pembuatan membran monomer yang telah menjadi rantai pendek lebih mudah terikat dengan pelarut dan membentuk senyawa kompleks yang dapat merubah sifat permukaan membran sebagaimana yang diinginkan. Ikatan hidrogen yang terjadi antara ion hidroksil dengan monomer polyvinylidene fuoride merupakan ikatan yang memudahkan untuk membentuk senyawa kompleks yang dimaksud, dan terutama dalam penambahan aditif untuk memodifikasi morfologi dan struktural membran.

Pada penelitian ini digunakan membran PVDF untuk memfiltrasi limbah cair industri tekstil eco-print. Industri ini menggunakan pewarna alami yang dicampur dengan pemekat warna yang terdiri dari kaporit yang terdiri dari klor dan juga menggunakan serbuk besi untuk penguat warna kain. Senyawa ini menyebabkan pencemaran jika tidak dikontrol pembuangannya sehingga pengelolaan air limbah industri tekstil ini dapat sesuai dengan baku mutu yang ditetapkan melalui penggunaan 
teknologi membran. Standarisasi produk filtrasi dalam teknologi membran telah ditabulasikan pada Tabel 1 berikut berdasarkan SNI, 2016. Retensi yang dihasilkan dalam penelitian ini telah memenuhi standar sehingga membran PVDF untuk filtrasi limbah cair industri tekstil dapat dikembangkan untuk mendapatkan hasil terbaik.

Tabel 1. Standar limbah cair industri tekstil

\begin{tabular}{|c|c|c|c|}
\hline \multirow[t]{2}{*}{ Parameter } & \multirow{2}{*}{$\begin{array}{l}\text { Kandungan } \\
\text { Maksimum } \\
(\mathrm{mg} / \mathrm{L})\end{array}$} & \multicolumn{2}{|c|}{$\begin{array}{l}\text { Jumlah maksimum } \\
\text { polutan (kg.ton) }\end{array}$} \\
\hline & & Sumber & Tepi sungai \\
\hline BOD & 60 & 97 & 67 \\
\hline COD & 15 & 105 & 80 \\
\hline TSS & 50 & 0,9 & 1,0 \\
\hline Fenol & 0,5 & 0,083 & 0,055 \\
\hline $\begin{array}{l}\text { Nitrogen } \\
\text { amonia }\end{array}$ & 8,0 & 6,3 & 0,32 \\
\hline Kekeruhan & 25 & 32,1 & 29,4 \\
\hline Warna & 50 & 339,0 & 120,0 \\
\hline $\mathrm{pH}$ & $6,0-9,0$ & & \\
\hline \multicolumn{2}{|c|}{$\begin{array}{l}\text { Jumlah buangan } \\
\text { maksimum (m3/ton) }\end{array}$} & 18 & 20 \\
\hline
\end{tabular}

\section{METODE PENELITIAN}

\section{Persiapan pembuatan membran}

Membran PVDF dihasilkan dengan metode dry-jet wet spinning pada suhu kamar $\left(25^{\circ} \mathrm{C}\right)$. Solusi pemintalan membran PVDF dibagi menjadi dua kelompok, yaitu membran dibuat dari 17 wt.\% PVDF dalam pelarut Dimethyl Formamide (DMF) pada konsentrasi $\mathrm{TiO}_{2}$ yang berbeda yaitu 3, 5 dan $10 \%$ berat dari massa PVDF. Secara umum, larutan polimer diberi tekanan melalui alat pemintal dengan laju ekstrusi terkontrol, sedangkan koagulan internal diatur pada $1,5 \mathrm{~mL} /$ menit. Membran berongga yang dihasilkan dari ujung alat pemintal diulurkan melalui dua penangas air dengan kecepatan pengambilan 13,5 $\mathrm{cm} /$ detik, secara hati-hati disesuaikan agar kecepatan jatuh bebasnya sebelum mencapai pada bak penampung akhir untuk menyelesaikan proses pemadatan. Membran berongga kemudian direndam dalam air selama 3 hari, dengan penggantian air setiap hari, untuk menghilangkan sisa pelarut dan aditif. Serat berlubang kemudian diolah menggunakan larutan gliserol $10 \%(\mathrm{v} / \mathrm{v})$ sebagai pertukaran non-pelarut selama 1 hari untuk meminimalkan penyusutan membran dan penyusutan pori. Kemudian membran dikeringkan selama 3 hari dan membran siap untuk dibuat modul uji membran berongga.

\section{Proses Ultrafiltrasi}

Percobaan filtrasi ini dilakukan dalam kondisi vakum yang dibuat menggunakan pompa peristaltik (Master flex model 7553-79, Cole Palmer) dengan permeat yang disedot dari ujung terbuka serat sebagaimana yang diilustrasikan pada Gambar 2 (Yuliwati, Porawati, and Elfidiah, and Melani 2019). Level cairan di tangki umpan dipertahankan konstan selama percobaan. Gelembung udara yang dihasilkan bermanfaat untuk memberikan tegangan geser untuk meminimalkan partikel yang mengendap di permukaan membran selama proses filtrasi. Volume permeasi air yang dikumpulkan ditentukan dengan menggunakan silinder ukur. Setelah filtrasi selesai, permukaan membran dibersihkan dengan spons lembut untuk menghilangkan lapisan penuh partikel yang mungkin terbentuk selama filtrasi.

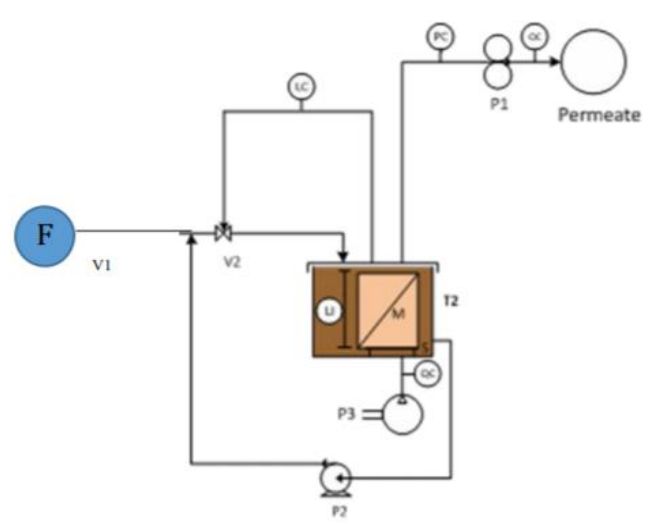

Gambar 2. Skema penelitian menggunakan membran PVDF berongga.

Fluks permeasi dan rejeksi membran PVDF untuk limbah cair tekstil eco-print, tercantum pada Tabel 2, diukur dengan sistem ultrafiltrasi. Modul membran dengan area filtrasi $16.00 \mathrm{dm}^{2}$, direndam dalam suspensi limbah cair yang telah disiapkan dalam reservoir membran dengan kapasitas $15 \mathrm{~L}$. Aliran silang dihasilkan oleh gelembung udara dari diffuser yang terletak di bawah modul membran terendam, untuk pembersihan mekanis dari modul membran. Laju aliran gelembung udara per unit area membran 
proyeksi diatur secara konstan pada $2,5 \mathrm{~mL} /$ menit untuk mempertahankan turbulensi yang tepat. Tekanan filtrasi diberikan oleh pompa vakum dan dikendalikan katup jarum. Laju aliran permeate dicatat secara kontinyu menggunakan flow meter.

Kualitas air permeasi dari air limbah berminyak yang diolah oleh membran yang dimodifikasi menunjukkan bahwa membran memiliki kinerja antifouling yang baik (Yuliwati, Porawati, and Elfidiah, and Melani 2019). Membran memiliki aplikasi yang luas dalam pengolahan air limbah tekstil dengan perolehan fluks yang lebih tinggi dan kontaminan yang lebih sedikit. Studi dari Yan menunjukkan bahwa penambahan partikel alumina berukuran nano dalam PVDF dapat meningkatkan fluks secara signifikan. Peningkatan retensi Total Organic Carbon (TOC) dari air permeasi sangat signifikan. Hal ini dapat dijelaskan bahwa penambahan partikel titanium dioksida hidrofilik pada membran hasil modifikasi dapat menghilangkan kontaminan organik secara lebih efektif, dimana jumlah kontaminan organik yang melewati membran dengan air perembesan berkurang.

Fluks (J) diukur setelah fluks stabil, kemudian dihitung sebagai

$$
\mathrm{J}=\frac{V}{A \cdot t}
$$

dimana $\mathrm{J}$ adalah fluks air murni $\left(\mathrm{L} / \mathrm{m}^{2} . \mathrm{h}\right), \mathrm{V}$ adalah volume permeat (L), A adalah luas membran $\left(\mathrm{m}^{2}\right)$ dan $\mathrm{t}$ adalah waktu $(\mathrm{h})$.

Persentase retensi $(\mathrm{R})$ membran berongga dihitung dengan menggunakan persamaan (2). Rejeksi dikarakterisasi dengan larutan air setelah membran sebelumnya disaring dengan air murni hingga fluks stabil, yang dihitung menggunakan persamaan berikut,

$$
R=\left(1-\frac{C p}{C j}\right) .100 \%
$$

dimana $\mathrm{R}$ adalah retensi membran, $C p$ adalah konsentrasi perembesan dan $C j$ adalah konsentrasi umpan.

(Kusworo, T.D., Pratama, B.A. 2020) dan (Loh 2017) mengamati penurunan konsentrasi chemical oxygen demand (COD) dan total organic carbon (TOC), dicapai dengan mempertimbangkan kompleksitas air limbah yang diproses. Membran dapat meningkatkan efisiensi penurunan COD sebesar $17 \%$ dan TOC sebesar $20 \%$, dibandingkan dengan hasil yang diperoleh hanya dengan bioseparasi. Penurunan konsentrasi chemical oxygen demand (COD), biochemical oxygen demand (BOD) dan total organic carbon (TOC) di unit pengolahan air limbah tekstil menunjukkan bahwa peningkatan sekecil apapun, dapat dihitung dari analisis model transportasi COD berikut:

$$
\frac{1}{R_{C O D}}=\frac{1}{R_{S C O D}}+\frac{B_{s C O D}}{R_{S C O D}} \cdot \frac{1}{J_{v}}
$$

dimana $\mathrm{R}_{\mathrm{COD}}$ adalah retensi keseluruhan COD, RsCOD adalah parameter retensi keseluruhan untuk COD, BsCOD adalah parameter perpindahan massa keseluruhan untuk COD dan adalah fluks permeat.

Berdasarkan persamaan 3, peningkatan tekanan transmembran menyebabkan fluks permeat meningkat sejak $1 / \mathrm{R}_{\mathrm{COD}}$ menurun dan $\mathrm{R}_{\mathrm{COD}}$ meningkat. Ini adalah studi yang sangat menarik dimana penolakan COD yang lebih tinggi dicapai dengan peningkatan fluks permeat. Selain itu, sebagaimana yang diketahui dalam proses menggunakan membran, pengotoran membran merupakan fenomena kompleks di mana fluks permeat menurun drastis karena fenomena yang melibatkan faktor kimia dan fisik (Yuliwati $\mathrm{dkk}, 2011)$. Hal ini merupakan hasil dari adsorpsi komponen larutan umpan ke bahan membran.

Ada dua jenis fouling membran untuk pengolahan air limbah berminyak. Salah satunya adalah fouling yang dapat dibalik, yang biasanya disebabkan oleh partikel zat terlarut atau koloid yang mengendap di permukaan dan di pori-pori. Fouling lainnya adalah pengotoran ireversibel, yang menyebabkan penurunan fluks karena penyerapan fisik atau kimiawi zat terlarut dan partikel yang kuat di permukaan dan di pori-pori membran. Penurunan fluks yang disebabkan oleh pengotoran yang tidak dapat diubah hanya dapat dipulihkan dengan mencuci dengan larutan asam atau alkali (Yuliwati et al. 2011). 
Mekanisme fouling selalu diawali dengan periode induksi. Periode induksi adalah sistem fungsi dan kondisi operasi. Karena kecenderungan fouling merupakan fungsi dari fluks dan kecepatan aliran silang, telah dilaporkan oleh (Madrakian, T., Afkhami, A., \& Bagheti 2011), bahwa membran $\mathrm{PVDF} / \mathrm{Al}_{2} \mathrm{O}_{3}$ yang dimodifikasi memiliki kinerja anti fouling yang menguntungkan dengan pemulihan fluks yang lebih baik dan adsorpsi kontaminan yang lebih sedikit.

\section{HASIL DAN PEMBAHASAN}

\section{Struktur dan Morfologi Membran}

Pada Gambar 2, struktur dan morfologi membran diilustrasikan pada bagian potongan melintang dan permukaan luarnya. Gambar 3 menunjukkan gambar AFM 3D dari permukaan luar PVDF membran berongga. AFM mengungkapkan bahwa permukaan membran tidak mulus dan struktur seperti nodul dan agregat nodul terbentuk pada permukaan membran PVDF. Derajat kekasaran permukaan (Ra) dihasilkan masing-masing sebagai 12,28 $\mathrm{nm}, 18,65 \mathrm{~nm}$ dan 20,58 nm untuk PVDF dengan $3 \% \mathrm{TiO}_{2}$, PVDF dengan $5 \% \mathrm{TiO}_{2}$ dan PVDF dengan $10 \% \quad \mathrm{TiO}_{2}$. Dapat diketahui bahwa rata-rata parameter kekasaran meningkat dengan peningkatan jumlah aditif dalam membran PVDF. Hasil ini mungkin disebabkan karena permukaan luar membran mengalami penggabungan dan orientasi agregat polimer dalam wadah koagulasi eksternal saat peredaman membran. Ketika larutan polimer keluar dari spinneret, relaksasi polimer terjadi pada permukaan luar. Selama relaksasi, makromolekul cenderung menggulung dan terjerat satu sama lain, meningkatkan fusi agregat nodular seperti yang dapat dilihat pada Gambar 3. Tekanan yang mempengaruhi secara dramatis pada molekul polimer mengakibatkan relaksasi di permukaan luar membran sebagaimana yang didapatkan pada berbagai studi oleh (L.Y. Susan, Suzylawati Ismail, Ooi Boon Seng, H. Mustapa 2017); (V.K. Garg, M. Amita, R. Kumar, R. 2004).

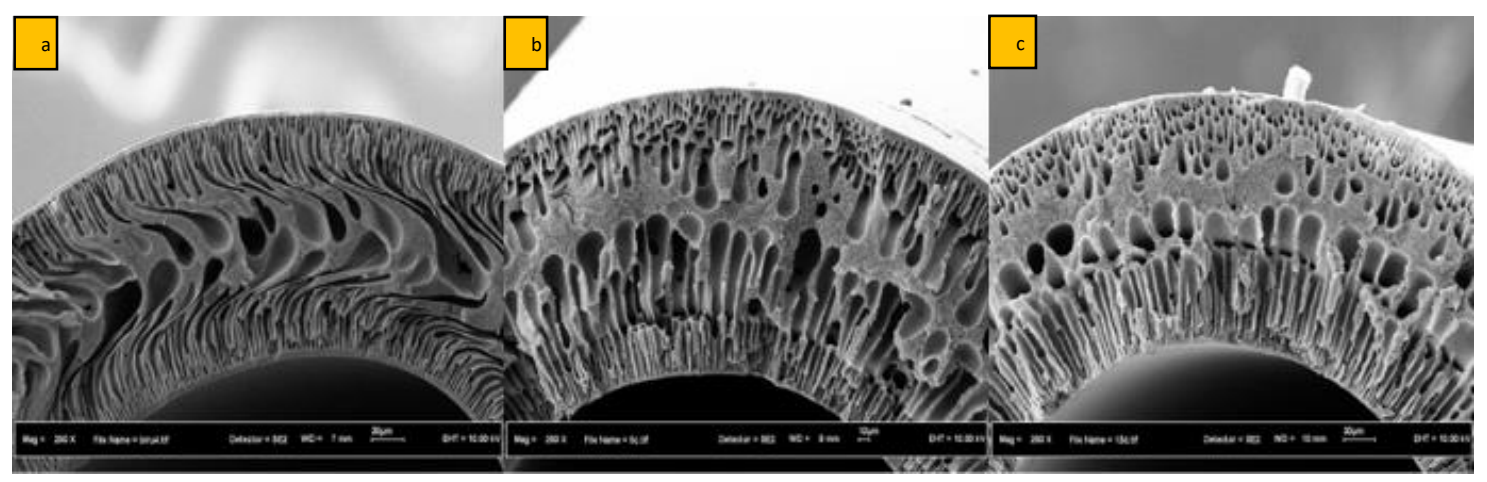

Gambar 2. Potongan melintang membran melalui FESEM dari PVDF membran modifikasi (1) lapisan dalam (2) lapisan tengah (3) lapisan luar.
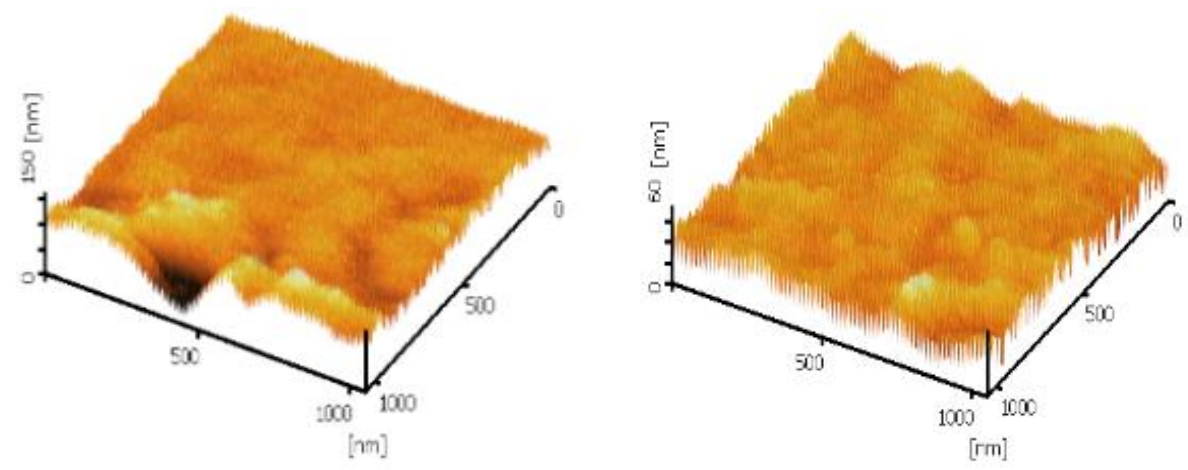

Gambar 3. AFM permukaan luar membran 


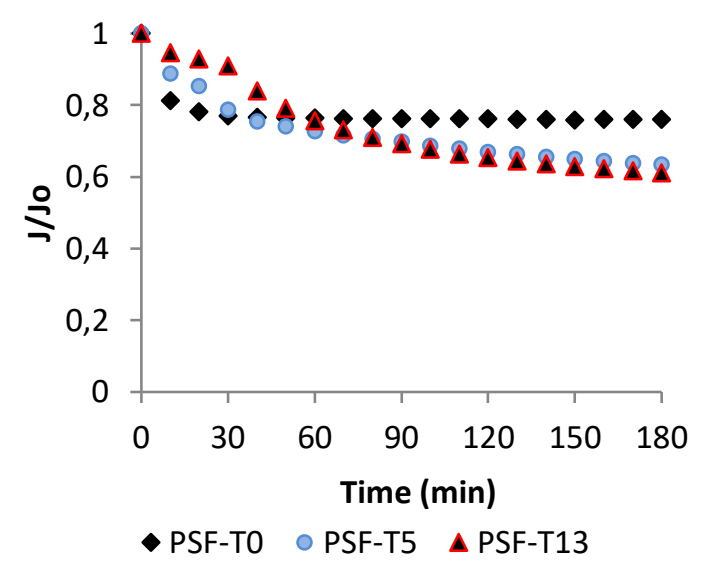

Gambar 4. Fluks dari variasi penambahan aditif titanium dioksida.

\section{Permeabilitas membran}

Fluks membran PSf yang dimodifikasi ditemukan meningkat dengan peningkatan komposisi aditif. Gambar 4 menunjukkan penurunan permeabilitas relatif membran PVDF dengan penambahan aditif pada konsentrasi yang berbeda dengan $\left(J_{\mathrm{o}}\right)$ sebagai fungsi waktu. Pada Gambar 5 terjadi pengurangan cukup signifikan dari permeabilitas relatif diamati. Hal ini merupakan konsekuensi dari pengotoran membran oleh limbah cair tekstil.

Kinerja ketiga membran filtrasi ditunjukkan pada Gambar 5, dimana membran PVDF denga $10 \% \quad \mathrm{TiO}_{2}$ memiliki kinerja terbaik dengan rejeksi $93,2 \%$. Terlihat jelas bahwa permeabilitas membran menurun drastis dalam 30 menit filtrasi ketika rejeksi awal tinggi dari tahap filtrasi awal seperti yang ditunjukkan pada Gambar 5. Hal ini menunjukkan bahwa penolakan awal membran merupakan faktor kunci penurunan fluks yang tinggi. Dengan demikian, rejeksi membran menjadi lebih tinggi karena ukuran pori menjadi lebih kecil (N. 1967).

Rejeksi membran PVDF dengan 3\% $\mathrm{TiO}_{2}$ dan PVDF dengan 5\% $\mathrm{TiO}_{2}$ masing-masing adalah $82,8 \%$ dan $75,2 \%$, yang menunjukkan bahwa ukuran pori untuk kedua membran ini sangat mempengaruhinya yang disebabkan penambahan aditif $\mathrm{TiO}_{2}$. Pori-pori membran yang lebih besar akan menyebabkan COD,

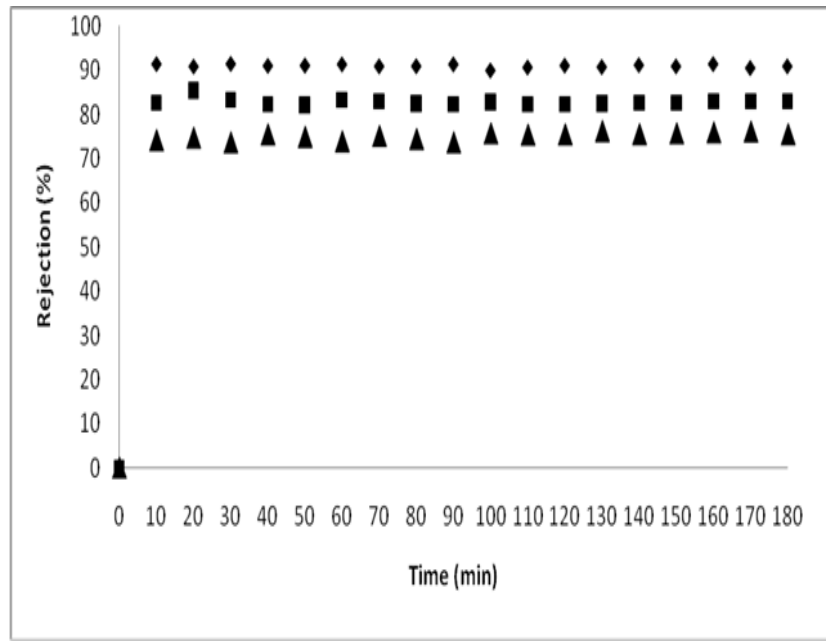

Gambar 5. Pengaruh waktu terhadap rejeksi.

BOD dan TOC lebih mudah masuk melalui pori-pori dan menghasilkan pemisahan zat terlarut yang lebih rendah. Terjadi penurunan rejeksi yang diakibatkan dengan bertambahnya ukuran pori permukaan terluar juga diteliti oleh Ezekannagha dkk melalui proses metanolisi minyak. Dengan kata lain, hal ini menunjukkan bahwa transpor zat terlarut dapat diatur oleh ukuran pori dan distribusi ukuran pori dari permukaan luar membran PVDF berongga. Dalam penelitian sebelumnya oleh (S.K. Giri, N.N. Das 2011), (Liou 2010), (Susan, Ismail, and Ooi Boon Seng 2017), dan (Vijayasanthi et al. 2020), ditemukan nilai pemisahan zat terlarut yang lebih rendah untuk membran serat berongga yang memiliki ukuran pori yang lebih besar.

Dalam studi membran PVDF dengan 3\% $\mathrm{TiO}_{2}$ dan $5 \% \mathrm{TiO}_{2}$, permeabilitas menurun jauh lebih lambat dibandingkan dengan PVDF dengan $10 \% \quad \mathrm{TiO}_{2}$, dimana membran PVDF dengan $10 \% \mathrm{TiO}_{2}$ tetap memiliki permeabilitas tertinggi. Hal ini dibuktikan dengan hasil filtrasi seperti ditabulasikan pada Tabel 2.

Tabel 2. Hasil filtrasi limbah tekstil eco-print

\begin{tabular}{lc}
\hline Parameter, satuan & Hasil Filtrasi \\
\hline Fluks, $\mathrm{L} / \mathrm{m}^{3} \mathrm{H}$ & 142,92 \\
COD \% & 90,08 \\
BOD, \% & 85,92 \\
TOC, \% & 92,34 \\
\hline
\end{tabular}




\section{KESIMPULAN}

Membran PVDF berongga yang diberi aditif $\mathrm{TiO}_{2}$ dengan berbagai konsentrasi dapat meningkatkan laju fase inversi dan menyediakan membran asimetris berpori dengan struktur canggih untuk pengolahan air limbah tekstil eco-print. Beberapa teknik karakterisasi dan pengukuran seperti struktur membran, dan permeabilitas digunakan untuk mengevaluasi detail struktur halus membran dan kinerja membran. Analisis FESEM menunjukkan bahwa penambahan 10 wt.\% berat $\mathrm{TiO}_{2}$ menghasilkan membran yang memiliki hidrofilisitas yang lebih tinggi, ukuran pori yang kecil, dan porositas yang tinggi. Analisis AFM menggambarkan kekasaran permukaan luar membran, yang mengakibatkan peningkatan $\mathrm{Ra}$ dengan peningkatan komposisi aditif. Hasil uji permeabilitas menggambarkan bahwa nanopartikel $\mathrm{TiO}_{2}$ sangat mempengaruhi kinerja membran PVDF berongga. Fluks yang lebih tinggi secara signifikan mencapai 142,92 $\mathrm{L} / \mathrm{m}^{2} \mathrm{~h}$ pengolahan air limbah tekstil eco-print, pengurangan persentase COD sebesar $90,08 \%$, BOD sebesar $85,92 \%$ dan TOC sebesar $92,34 \%$.

\section{SARAN}

Penambahan material aditif oksida disarankan untuk penelitian lanjutan dengan tujuan meningkatkan permukaan adsorpsi pada proses filtrasi, dimana polimer yang digunakan adalah campuran polimer untuk membentuk struktur mixed matrix pada morfologi membran. Hal ini diharapkan dapat meningkatkan kinerja membran.

\section{DAFTAR PUSTAKA}

Ezekannagha, Chinyere B, Callistus N Ude, and Okechukwu D Onukwuli. 2017. "Optimization of the Methanolysis of Lard Oil in the Production of Biodiesel with Response Surface Methodology." Egyptian Journal of Petroleum 26 (4): 1001-11.

Han, X., and and Xiaojian Ma Xiaona Niu. 2012. "Adsorption Characteristics of
Methylene Blue on Poplar Leaf in Batch Mode: Equilibrium, Kinetics and Thermodynamics." Korean Journal of Chemical Engineering 29 (4): 494-502.

Kusworo, T.D., Pratama, B.A., \& Savira D.P. 2020. "Optimization of Bio-Oil Production from Empty Palm Fruit Bunces by Pirolysis Using Response Surface Methodology." Reaktor 2(1): 1-9.

Liese, W., \& Kohl, M. 2015. Bamboo: The Plant and Its Uses. Springer International Publishing.

Liou, T. H. 2010. "Development of Mesoporous Structure and High Adsorption Capacity of Biomass-Based Activated Carbon by Phosporic Acid and Zinc Chloride Activation." Chemical Engineering Journal.

Loh, S. K. 2017. "The Potential of the Malaysian Oil Palm Biomass as a Renewable Energy Source." Energy Conversion and Management 141: 28598.

Madrakian, T., Afkhami, A., \& Bagheti, H. 2011. "Removal of Some Cationic Dyes from Aquaeous Solutions Using Magnetic Modified Multi-Walled Carbon Nanotubes." J. Hazard. Mater 196: 10914.

N., M. Xiaojian H. Xiuli N. Xiaona. 1967. "Adsorption Characteristics of Methylene Blue on Poplar Leaf in Batch Mode: Equilibrium, Kinetics and Thermodynamics." Angewandte Chemie International Edition, 6(11), 951-952. 29(4): 494-502.

S.C., Yu, S.C. \& Gao, C.J. 2017. "Research on PVDF UF Membrane with Small Pore Size.” J. Tech. Water Treat 25(2): 83-86.

S.K. Giri, N.N. Das, G.C. Pradhan. 2011. "Magnetic Powder and Kaolinite Derived from Waste Iron Ore Tailings for Environmental Applications." Powder Technology 214: 513-18. 
Susan, L.Y., Suzylawati Ismail, and and H. Mustapa Ooi Boon Seng. 2017. "Surface Morphology of Pvdf Membrane and Its Fouling Phenomenon by Crude Oil Emulsion." Journal of Water Process Engineering 25 (2): 55-61.

V.K. Garg, M. Amita, R. Kumar, R., Gupta. 2004. "Basic Dye (Methylene Blue), Removal from Simulated Wastewater by Adsorption Using Indian Rosewood Sawdust." Dyes Pigments 63: 243-50.

Vijayasanthi, J., R. Sachin, R. Adsare, Aduja Naik Archana G. Lamdande, and and G. Prabhakar K. S. M. S. Raghavarao. 2020. "Recovery of Proteins from Coconut Milk Whey Employing Ultrafiltration and Spray Drying." Journal of Food Science and Technology 57 (1): 22-31.

Yuliwati, E., A.F. Ismail, T. Matsuura, and and M.S. Abdullah M.A. Kassim. 2011. "Effect of Modified PVDF Hollow Fiber Submerged Ultrafiltration Membrane for Refinery Wastewater Treatment." Desalination 283: 214-20.

Yuliwati, E., and A.F. Ismail. 2011. "Effect of Additives Concentration on the Surface Properties and Performance of PVDF Ultrafiltration Membranes for Refinery Produced Wastewater Treatment." Desalination 273 (1): 226-31.

Yuliwati, E., H. Porawati, and A. Elfidiah, and Melani. 2019. "Performance of Composite Membrane for Palm Oil Wastewater Treatment." Journal Applied Membrane Science \& Technology 23 (2): 1-10.

Yuliwati, E, A F Ismail, T Matsuura, M A Kassim, and M S Abdullah. 2011. "Characterization of Surface-Modified Porous PVDF Hollow Fibers for Refinery Wastewater Treatment Using Microscopic Observation." Desalination 283: 206-13. 